\title{
CHINESE HYBRID WARFARE APPROACH AND THE LOGIC OF STRATEGY
}

Pregledni rad (Review Paper)

Received: 25 October 2021

Accepted: 20 December 2021

DOI: https://doi.org/10.37458/nstf.23.1.3

\section{Laris Gaiser *}

\section{Abstract}

The geopolitical, military, and economic development of the People's Republic of China (PRC) represents a challenge to the world order that international actors will have to manage in the coming years. The destructuring approach of the current international system, based on US pre-eminence, is attacked simultaneously in three fields ${ }^{1}$. It is a method that does not respect the rules of strategic logic and is capable of leading to the collapse of the Chinese regime due to the strong international friction it will create ${ }^{2}$. The strategic realignment of

* Laris Gaiser is associate professor of security studies and macroeconomy.

${ }^{1}$ Gaiser, L. (2020). Il Dragone nei Balcani. In F. Gaglietti (ed.). Contagio Rosso. Roma: Giubilei Regnani

${ }^{2}$ Luttwak, E. (2012). The Rise of China vs. the Logic of Strategy. Cambridge: Harvard University Press 
the United Kingdom, USA, Japan, and Australia that has been in place since 2021 to contain China's international activism is a signal of a highly protective containment strategy currently deployed by the western allies led by Washington, but it is especially proof that Chinese policies are creating counterreactions.

\section{Keywords: China, Hybrid warfare, Strategy, Military power, communist party}

\section{Introduction}

From the point of view of strategic science, if Beijing does not change its posture, conflict seems inevitable. The logic of its expansionism is unsustainable both theoretically and factually. Challenging adversary systems, declaring the desire for world leadership creates frictions both with closest neighbours and most distant contenders alike.

This article, by analysing planning documents made public by the Chinese state, intends to prove that the Chinese regime is adopting an overall military strategy, part of a broader vision of hybrid warfare, which proves that the regime does not understand the risk of generalized conflict to which it is facing by not withdrawing from its allencompassing approach to contemporary confrontation on all three levels of strategy. However, the PRC is an important member of the international economic system, and classical containment - as implemented in the past against an economic dwarf like the Soviet Union - cannot work if the result is a regime change and country collapse. The Chinese Communist Party (CCP) represents an authoritarian threat taking strategically wrong decisions that could bring the country into an open conflict.

For this reason, antagonistic forces need to be critically aware of the situation to avoid an open-ended, waged confrontation and should focus on ways to smartly influence a smooth re-heading of the country. The final goal for liberal 
democracies should be a regime change that doesn't damage the country's wealth ${ }^{3}$.

\section{Strategy and Mistakes}

In his speech marking the 100th anniversary of the Chinese Communist Party, General Secretary Xi Jinping said a strong country must have a strong military force to guarantee the security of the nation. He defined the People's Liberation Army as a "strong pillar" for safeguarding the country and preserving national dignity, sovereignty, and development interests in China and the region beyond. Furthermore, Xi remarked that the Army must be grown and elevated "to world-class standards". ${ }^{4}$

Xi's statements declare not only the importance of military power in the conquest and maintenance of Chinese Communist Party political power for the last hundred years but, above all, they are the proof of a linear development of the country's military capabilities that the Party, the supreme commander, continues to support by updating previous strategies.

Within such a scenario, the PRC implements a hybrid warfare strategy that serves the project of Chinese regional and global predominance 5 .

In 2003, China issued a document, The Political Work Guidelines of the People's Liberation Army, which described the application of the so-called Three warfare's to be

${ }^{3}$ Pelanda, C. (2020). La Questione Cinese. In F. Gaglietti (ed.). Contagio Rosso. Roma: Giubilei Regnani

${ }^{4}$ Davidson, H. (2021). Xi Jinping warns China won't be bullied in speech marking 100-year anniversary of CCP. Available at: https://www.theguardian.com/world/2021/jul/01/xi-jinping-warns-china-wontbe-bullied-100-year-anniversary-chinese-communist-party- (Accessed: 05.11.2021)

${ }^{5}$ EGE (2020). La Chine comunist est-elle devenue un puissance dangereuse du temp de paix?. Paris: Ecole de Guere Economique. 
applied both during peacetime and wartime operations ${ }^{6}$. The first one, psychological warfare, refers to the application of both military and diplomatic measures aimed at disrupting adversaries' will to oppose China's foreign policy objectives. The second type, opinion warfare, concerns the implementation of overt and covert media manipulations, e.g., the use of distorted information, spread out through the media to influence international as well as domestic audiences about the rightness of Chinese foreign policy conduct. Finally, the third type, legal warfare, refers to the exploitation of all international norms to make sure of fulfilling China's objectives while also undermining other states' foreign policy goals through the international fora. The given framework, together with China's historical ability to perform asymmetric warfare, as attested to during the civil war and beyond, explains how the PRC is becoming a crucial actor in deploying hybrid warfare capabilities covering several fields simultaneously?

However, as argued by Luttwak in his book The Rise of China vs. the Logic of Strategy, the

dominant Chinese strategic and cultural arrogance could undermine efforts to lift the Middle Kingdom to the ranks of true superpower status. PRC leaders try to simultaneously achieve rapid growth in economic capacity, military power, and global, diplomatic influence. This means that the Chinese leaders are ignoring the basic logic of strategic science teaching that by accumulating more power simultaneously in all three fields, a resistance will mount that can condemn the author to destabilize itself. For Luttwak, China's assumption of cultural and intellectual superiority is driving its neighbours into a camp of strategic containment similar to what Germany created for itself in the years leading up to World War I.

${ }^{6}$ Central Military Commission (2003).Political Work Guidelines of the People's Liberation Army. Beijing: CMC.

7 Miracola, S. (2018). Chinese Hybrid Warfare. Available at: https://www.ispionline.it/en/pubblicazione/chinese-hybrid-warfare-21853 (Accessed: 05.11.2021) 


\section{Chinese Military Power Development}

Given the above assumption, it is important for international stability to define if the PRC understands the contradiction of its strategy and if, consequently, it changes its approach, specifically limiting the PLA's role in foreign policy or hybrid warfare.

According to Sergio Miracola's analysis, the past seventy years of Chinese military history can be split into two phases. The first one is related to the Mao era of revolutionary doctrine, Deng era of modernization doctrine, and the Jiang era of high-tech doctrine. The second, inevitably built upon the previous one, comprises the Hu Jintao and Xi Jinping era.

Mao's fundamental principles were based on the belief that people - not machines - retained the ability to fight and win wars in the name of the Party, an approach linked to ancient Chinese tradition, which set a crucial precedent for China's current military development, that is, the civilianmilitary fusion ${ }^{8}$. To succeed, the people's war needed to apply two fundamental conditions: the principle of active defence and the principle of protracted warfare.

With Deng Xiaoping, from 1978 to 1992, the doctrine of the people's war changed into the people's war under modern conditions. The fundamental idea conceived the establishment of a professional army and a technological apparatus to defend China's coastal waters and territory outside its national boundaries. Following this strategic guideline, Deng decided to set up the famous "863 Plan" in 1986, whose objective concerned the transformation of overall Chinese technological development to supply the army with sophisticated weapons for war ${ }^{9}$. The technological variable introduced by Deng Xiaoping as an overarching programme of national industrialization with inevitable spillover effects

8 US Secretary of Defense (2020). Civilian-Military Fusion. Available at: https:/www.state.gov/wp-content/uploads/2020/05/What-is-MCF-One-

Pager.pdf (Accessed: 05.11.2021);

${ }^{9}$ Ministry of Science and Technology PRC (1986). The National High Technology Programme (863 Programme). Beijing: MoST; 
on the military became a central component of military strategy under the leadership of Jiang Zemin. He can easily be recognized as the founding father of the modern Chinese professional army, a professionalization based mainly on lessons learned on the outputs of the First Gulf War in 1991, which exerted a deep influence on Chinese leaders since it changed the paradigm of war due to the implementation of information warfare.

Consequently, Jiang Zemin coined the new strategic guidance of winning local wars under high technological conditions. With this new military strategy in place, the Chinese government started a robust programme to achieve army, air force, navy, space, and cyber modernization. The development of cyber capabilities followed the Chinese historical tradition of civil-military fusion outlined above. Jiang Zemin had, in fact, promoted a civil-military integration throughout the 90 s, locating the military within the civilian. ${ }^{10}$

Under Hu Jintao's presidency, it became evident that the modernization process of the army was now unstoppable. In line with his predecessor's strategic thought, Hu Jintao simply strengthened the existent strategic guideline of winning local wars under high-tech conditions by rephrasing it as winning local wars under informationized conditions. The idea was to strengthen China's overall digital and information systems to increase the strength of cyber capabilities along with the overall command structure for joint military operations.

However, Hu Jintao did not stop there. He also gave the army a new boost in terms of grand strategy by promoting the so-called Army's new historic missions for the new century in December 2004, identifying the four major missions that the army would undertake for the new century as China's international commitments abroad expanded ${ }^{11}$. They were:

${ }^{10}$ Miracola, S. (2019). The evolution of China's Army and Military Strategy. Available at: https://www.ispionline.it/en/pubblicazione/evolution-chinas-armyand-military-strategy-24040 (Accessed: 05.11.2021).

${ }^{11}$ Mulvenon, J. (2008). Chairman Hu and the PLA's "New Historic Missions". China Leadership Monitor, 27. 1-11. 
1) Providing an important guarantee of strength for the Party to consolidate its ruling position

2) Providing a strong security guarantee for safeguarding the period of important strategic opportunity for national development

3) Providing a powerful strategic support for safeguarding national interests

4) Playing an important role in safeguarding world peace and promoting common development

In 2013, under the leadership of Xi Jinping, the Chinese Academy of Military Science issued a new official military handbook, the Science of Military Strategy, through which the central government explained China's overall national security strategy ${ }^{12}$, the five-dimensional nature of war, and China's major geopolitical challenges for the new century.

The second big transformation occurred in 2015, with the issue of its 10th defence white paper entitled, China's Military Strategy. In this document, the previous winning local wars under informationized conditions was changed into winning informatized local wars, and the underpinning idea behind this principle was that China is now ready to expand its military efforts beyond its national boundaries. The inauguration of the first Chinese military base abroad - in Djibouti - in 2017 was the coronation of its stated intentions.

The introduction of the military-civilian fusion programme at a national level, which is intertwined with the national technological innovation programmes Made in China 2025 and the Three Years Action Plan to Promote the Development of a New-Generation $\mathrm{AI}^{13}$, brings the Chinese military capabilities toward the progressive intelligentization of warfare but especially demonstrates that China pursues its

12 Military Academy (2013). The Science of Military Strategy. Beijing: Military Academy.

13 The State Council (2017). New Generation Artificial Intelligence Development Plan. Beijing: The State Council Information Office of the People's Republic of China. 
target of inevitably becoming a world superpower ${ }^{14}$, competing directly with the US for spheres of influence, as attested by the Belt and Road Initiative, the growing need to support it through the use of the military capabilities, and by its latest defence white paper, China's National Defence in the New Era, issued in July 2019. A document that certainly is not diminishing the aggressive posture of the PRC towards global actors given that it flags the fact that America and China are now competing superpowers and that China's growing military forces are developing to the point where they will be able to challenge the United States ${ }^{15}$. Moreover, it describes Taiwanese, Tibetan, and Turkistan separatists as threats, calls upon a resolute response to any provocation on the sea, and sanctions against anybody supporting separatism; but it especially pretends the comprehensive implementation of Xi Jinping's thinking on strengthening the military power by taking all necessary measures to safeguard China's national sovereignty, security, and interests. By defining it as an "absence of threats", it allows a justification of any perceived threats towards the legitimacy and governance of the Chinese Communist Party to be quashed before they eventuate. By including national development as a key security issue, it broadens the scope of national-interest protection to include anything that can undermine the country's development. This is an overwhelming deterrence that results in an overwhelming declaration of claims.

\section{Conclusion:}

The article demonstrates that through the last seven decades, the PLA has enlarged its competencies and that since 2012, open support to the PLA, and its scopes, has increased. China's military expenditure passed from 191.6 billion USD in 2014 to 1.11 trillion USD in 2018 , and the PLA, as a proxy for China's information operations, distracts analysts from the much larger organizational and operational infrastructure that exists under the CCP and the State Council. Taking into

${ }^{14}$ Mingfu, L. (2010). The Chinese Dream. Beijing: Zhongguo Youyi Chuban Gongsi.

15 Cordesman, A. (2019). China's New 2019 Defense White Paper. Available at: https://www.csis.org/analysis/chinas-new-2019-defense-whitepaper (Accessed: 05.11.2021). 
account all the published strategies and legally binding PRC declared targets, continuous growth simultaneously in the economy, regional and global influence, and military strength, as well as the expanded use of hybrid warfare capabilities covering all the above-mentioned fields, we can conclude that the PRC is not (yet) taking into account the Logic of Strategy and it is destabilizing itself; creating resistance in a world of states that will continue to monitor, resist, deflect or counter Chinese power. Due to the very much proactive Beijing strategy and its leadership declarations, frictions with the outside world are mounting.

In doing so, China is doomed to fail in its race for world leadership. However, liberal democratic forces, which have given Beijing the chance to become one of the major economic players on the planet, will have to, for the sake of the Chinese people and international stability, opt for a flexible containment strategy that allows for an authoritarian regime change; without this leads to the socio-economic collapse of the country.

The future challenge is not so much whether the regime change will take place but how to manage it from the outside while avoiding an internal crisis that destabilizes the global economy. According to Pelanda, this objective could be achieved through a conditioning strategy shaped by liberal democracies pressuring China to renegotiate access to the international market and setting conditions of transparency based on the rule of law and respect for human rights. Conditionality should not demand an accelerated democratizing path but certainly a limitation of authoritarianism. In the Nineties, the US, together with its allies, facilitated China's entry into the global market, convinced of the inevitable victory of Western democratic principles. Never was an idealistic view more wrong. Political realism must now rediscover its creative strength by giving life to a conditional solution that avoids the growth of nationalism and the aggressiveness of the PRC but, above all, allows the Chinese to stay on the path of development already undertaken. 


\section{Literature:}

1. Central Military Commission (2003). Political Work Guidelines of the People's Liberation Army. Beijing: CMC.

2. Cordesman, A. (2019). China's New 2019 Defense White Paper. Available at: https://www.csis.org/analysis/chinasnew-2019-defense-white-paper (Accessed: 05.11.2021).

3. Davidson, H. (2021). Xi Jinping warns China won't be bullied in speech marking 100-year anniversary of CCP. Available at: https://www.theguardian.com/world/2021/jul/01/xi-jinpingwarns-china-wont-be-bullied-100-year-anniversarychinese-communist-party- (Accessed: 05.11.2021).

4. EGE (2020). La Chine comunist est-elle devenue un puissance dangereuse du temp de paix?. Paris: Ecole Economique de Gueree.

5. Gaiser, L. (2020). II Dragone nei Balcani. In F. Gaglietti (ed.). Contagio Rosso. Roma: Giubilei Regnani.

6. Luttwak, E. (2012). The Rise of China vs. the Logic of Strategy. Cambridge: Harvard University Press.

7. Military Academy (2013). The Science of Military Strategy. Beijing: Military Academy.

8. Mingfu, L. (2010). The Chinese Dream. Beijing: Zhongguo Youyi Chuban Gongsi.

9. Ministry of Science and Technology PRC (1986). The National High Technology Programme (863 Programme). Beijing: MoST.

10. Miracola, S. (2018). Chinese Hybrid Warfare. Available at: $\quad$ https://www.ispionline.it/en/pubblicazione/chinesehybrid-warfare-21853 (Accessed: 05.11.2021). 
11. Miracola, S. (2019). The evolution of China's Army and Military Strategy. Available at:

12. $h t t p s: / / w w w . i s p i o n l i n e . i t / e n / p u b b l i c a z i o n e / e v o l u t i o n-$ chinas-army-and-military-strategy-24040 (Accessed: 05.11.2021).

13. Mulvenon, J. (2008). Chairman Hu and the PLA's "New Historic Missions". China Leadership Monitor, 27. 1-11.

14. Pelanda, C. (2020). La Questione Cinese. In F. Gaglietti (ed.). Contagio Rosso. Roma: Giubilei Regnani.

15. The State Council (2015). Made in China 2025. Beijing: The State Council Information Office of the People's Republic of China.

16. The State Council (2017). New Generation Artificial Intelligence Development Plan. Beijing: The State Council Information Office of the People's Republic of China.

17. US Secretary of Defense (2020). Civilian-Military Fusion. Available at: https://www.state.gov/wpcontent/uploads/2020/05/What-is-MCF-One-Pager.pdf (Accessed: 05.11.2021). 